\title{
Relationship between self-esteem and stigmatization in psoriasis patients
}

\author{
Barbara Jankowiak ${ }^{1}$, Beata Kowalewska1, Elżbieta Krajewska-Kułak ${ }^{1}$ Dzmitry Fiodaravich Khvorik², \\ Wiaczesław Niczyporuk ${ }^{3}$
}

'Department of Integrated Medical Care, Medical University of Bialystok, Bialystok, Poland

2Department of Dermatovenerology, Medical University, Grodno, Belarus

${ }^{3}$ Faculty of Health Sciences, Lomza State University of Applied Sciences, Lomza, Poland

Adv Dermatol Allergol 2020; XXXVII (4): 597-602

DOI: https://doi.org/10.5114/ada.2020.93242

\begin{abstract}
Introduction: Psoriasis is classified as a psychosomatic disease since its development and outcome may be modulated by various psychological factors. Due to the presence of clinical signs visible to others and poor social awareness of the disease, psoriasis patients are not infrequently classified as different or stigmatized, and their value as human beings tends to decrease.

Aim: To analyse the relationship between self-esteem and stigmatization in psoriasis patients.

Material and methods: The study included 120 patients with psoriasis vulgaris. The study participants completed Polish versions of the Rosenberg Self-Esteem Scale (RSES) and the 6-Item Stigmatization Scale developed by Evers et al., as well as an original survey containing questions about their sociodemographic characteristics.

Results: Mean RSES score of the study participants was 24.1 points. Mean RSES score for female patients was nearly 2 points lower than the mean score for men. Analysis of Spearman's rho coefficients showed that the higher the self-esteem in the study participants the less often they considered themselves unattractive to others $(0.23)$, less often believed that people gaze at their skin lesions (0.23) or avoid them because of their condition (0.38). Conclusions: Our findings demonstrate clearly that both self-esteem and stigmatization are significant components of psoriasis' influence on the patient life. Psoriasis should not be considered merely as a somatic problem, but also as a significant psychological and social burden.
\end{abstract}

Key words: psoriasis, stigmatization, self-esteem.

\section{Introduction}

Psoriasis is a chronic, non-contagious, inflammatory disease of the skin, which affects up to $3 \%$ of the human population. Psoriasis is classified as a psychosomatic disease since its development and outcome may be modulated by various psychological factors, such as stress, sense of denial and depressed mood. All these factors may trigger the development of new disease foci or exacerbate already existing ones [1-3].

One consequence of psoriasis is its negative effect on the psychological sphere of the patient, self-esteem, and hence, quality of life. This effect is modulated not only by the topography of the lesions, stage of the disease, its duration and treatment but also by patient's psychological condition. The self-esteem of psoriasis patients may be influenced by their acceptance by close relatives, interactions with the others, and personal or professional accomplishments [4].

Self-esteem is defined as one's attitude towards the self, in particular competencies and other socially valued traits. According to Rosenberg, at various stages of their lives, people may evaluate themselves positively or negatively and have different attitudes toward their self. According to that author, high self-esteem is one's belief that he/she is "good enough", valued human being, and others are friendly and do not constitute a threat. In turn, low self-esteem corresponds to dissatisfaction with one's self and its denial. Individuals with low self-esteem are more likely to be hurt and have a hostile attitude to the others and the world in general [5-7].

Psoriasis is considered a stigmatizing disease. Following the idea proposed by an American sociologist Ervin Goofman, Link and Phelan in their paper entitled Con-

Address for correspondence: Barbara Jankowiak PhD, Department of Integrated Medical Care, Medical University of Bialystok, 7A MC Skłodowskiej St, 15-096 Białystok, Poland, phone: +48 8574855 28, e-mail:barbara.jankowiak@umb.edu.pl Received: 23.04.2019, accepted: 7.06.2019. 
ceptualizing stigma [8] defined stigmatization as a set of interrelated elements, such as labelling, stereotyping, distinguishing between "us" and "them", discrimination, loss of social status and emotional responses of both stigmatizing (anger, anxiety, mercy) and stigmatized ones (shame, embarrassment).

However, it should be remembered that stigmatization is particularly important for the structure of one's self. Whenever a stigma has been imprinted on one's self, such a person is no longer aware of his/her positive traits. As a result, the stigma becomes subjective and internalized, and one perceives himself/herself from a perspective of that label. Therefore, a person with low self-esteem is more likely to be socially denied and isolated. A stigmatized person will define himself/herself in terms of the stigmatization and treat himself/herself in accordance with the stigma $[9,10]$.

\section{Aim}

The aim of the study was to analyse the relationship between self-esteem and stigmatization in psoriasis patients.

\section{Material and methods}

The study included 120 patients diagnosed with plaque psoriasis (psoriasis vulgaris), among them 56 (46.7\%) women and 64 (53.3\%) men. The severity of psoriasis was assessed based on PASI scores. The scale is used for quantitative assessment of three clinical characteristics of psoriatic lesions: redness, thickness and scaling (scored from 0 to 4 ), and the area of skin involved (scored from 0 to 6). Only patients with plaque psoriasis and PASI scores $\leq 10$ were qualified for the study. Other inclusion criteria were: duration of the disease $>2$ years, age $\geq 18$ years, lack of somatic and mental comorbidities, and lack of major stressogenic events (e.g. job loss, divorce, funeral) during three months preceding the study. Descriptive statistics for patient age, duration of the disease and age at the diagnosis are presented in Table 1.

The study participants completed Polish versions of the Rosenberg Self-Esteem Scale (RSES) [6] and the 6-Item Stigmatization Scale developed by Evers et al. [11], as well as an original survey containing questions about their sociodemographic characteristics (sex, age, place of residence, marital status).
RSES is an instrument for the evaluation of general self-esteem, i.e. a relatively stable disposition defined as a subjective (positive or negative) attitude to one's self [6]. The scale consists of 10 statements describing respondent's attitude towards his/her self, each scored on a 4-item scale, from "strongly agree" (1 point), to "agree" (2 points), "disagree" (3 points) and "strongly disagree" (4 points). The overall score is calculated as the sum of scores for individual statements, after inverting the scores for items 1, 2, 4, 6 and 7. The crude score can range from 10 to 40 points. To verify whether the crude score corresponds to low or high self-esteem, it should be converted to sten score; the higher the latter, the higher one's selfesteem.

The 6-Item Stigmatization Scale consists of six single choice questions, each with four possible responses scored from 0 to 3 points: "not at all" (0 points), "sometimes" (1 point), "very often" (2 points) and "always" (3 points). The overall score can range from 0 points (complete lack of stigmatization) to 18 points (maximum sense of stigmatization) [11-14].

The protocol of the study was approved by the Local Bioethics Committee at the Medical University of Bialystok.

\section{Statistical analysis}

The results were subjected to statistical analysis with SPSS 17 package. The following tests were used during the analysis:

- Spearman's rank correlation, a non-parametric equivalent of the parametric Pearson's $r$-correlation. During the analysis of Spearman's correlation, individual results are assigned ranks. This allows for the analysis of relationships between variables expressed on various scales regardless of their distribution. Moreover, due to assigning the ranks, Spearman's rank correlation coefficients are less prone to the confounding effects of outliers.

- Mann-Whitney U-test, to compare two independent groups. A primary advantage of this test stems from the fact that it analyses variables that are at least ordinal (although they may be also quantitative). Further, Mann-Whitney $U$-test does not require equal sizes of the groups, normal distribution and homogeneous variances. All these characteristics make it a widely applied statistical test.

Table 1. Detailed descriptive statistics of patients' age

\begin{tabular}{lccccc}
\hline Patient characteristic & Mean & Median & Minimum & Maximum & SD \\
\hline Age & 44.3 & 41.0 & 18.0 & 72.0 & 13.0 \\
\hline Duration of the disease & 19.6 & 19.0 & 2.0 & 53.0 & 11.6 \\
\hline Age at the diagnosis & 21.0 & 19.0 & 8.0 & 63.0 & 11.6 \\
\hline PASI & 5.95 & 6.0 & 0 & 2.96 \\
\hline
\end{tabular}

SD-standard deviation. 
- Chi-squared $\left(\chi^{2}\right)$ test, to analyse relationships between pairs of nominal variables. The test is based on the comparison of observed values (empirical values obtained during the study) with the expected values (i.e. hypothetical values describing a situation when two variables are completely unrelated). A substantial (statistically significant) difference between the observed and expected values suggests that there is a relationship between the two analysed variables.

The result of each test was expressed as its significance level $p<0.05$, under the assumption that each statistically significant relationship found in the analysed sample could be generalized onto the whole population of psoriasis patients.

\section{Results}

\section{Self-esteem evaluated with the RSES}

Mean RSES score of the study participants was 24.1 points (Table 2). Mean score for women was 24.59 points $(\mathrm{Me}=24 ; \mathrm{SD}=3.62 ; \min .=18 ; \max .=26)$, and mean score for men was 26.48 points $(M e=26 ; S D=3.38$; $\min$. = 24; $\max .=39$ ).

When the crude results were converted to sten scores, the majority of female respondents (41.1\%) scored 5 or 6 , which corresponded to moderate self-esteem. No predominant self-esteem sten score could be identified among men due to a nearly even distribution of their crude results between various sten categories: 1 or 2 sten $-7.8 \%$; 3 or 4 sten $-23.4 \%$; 5 or 6 sten $-26.6 \%$; 7 or 8 sten $-28.1 \%$; 9 or 10 sten $-14.1 \%$.

\section{Analysis of the stigmatization level}

Analysis of the results obtained with the 6-Item Stigmatization Scale demonstrated that responding to the survey questions, most respondents chose answers "always" and "very often". Mean score for the study group was 9.85 points. Based on Spearman's rho values we analysed a relationship between age of the respondents and their stigmatization level. The analysis of correlation showed that the older the respondents, the less often they experienced stigmatization (Table 3).

Table 2. Rosenberg Self-Esteem Scale

\begin{tabular}{|c|c|c|c|c|c|}
\hline Scale RSES & $\begin{array}{l}\text { Strongly agree } \\
n / \%\end{array}$ & $\begin{array}{c}\text { Agree } \\
n / \%\end{array}$ & $\begin{array}{l}\text { Disagree } \\
n / \%\end{array}$ & $\begin{array}{l}\text { Strongly disagree } \\
n / \%\end{array}$ & $\begin{array}{l}\text { Mean } \pm \text { SD } \\
\text { [points] }\end{array}$ \\
\hline $\begin{array}{l}\text { I feel that I am a person of worth, at least on an } \\
\text { equal plane with others }\end{array}$ & $38 / 31.7$ & $36 / 30$ & $32 / 26.7$ & 14/11.7 & $2.18 \pm 1.01$ \\
\hline I feel that I have a number of good qualities & $35 / 29.2$ & $28 / 23.3$ & $36 / 30.0$ & $21 / 17.5$ & $2.35 \pm 1.07$ \\
\hline All in all. I am inclined to feel that I am a failure & $22 / 18.3$ & $39 / 32.5$ & $32 / 26.7$ & $27 / 22.5$ & $2.45 \pm 1.03$ \\
\hline I am able to do things as well as most other people & $41 / 34.2$ & $31 / 25.8$ & $29 / 24.2$ & 19/15.8 & $2.22 \pm 1.09$ \\
\hline I feel I do not have much to be proud of & $28 / 23.3$ & $35 / 29.2$ & $34 / 28.3$ & 23/19.2 & $2.43 \pm 1.05$ \\
\hline I take a positive attitude toward myself & $25 / 20.8$ & 22/18.3 & $55 / 45.8$ & $18 / 15.0$ & $2.55 \pm 0.99$ \\
\hline On the whole, I am satisfied with myself & $32 / 26.7$ & $26 / 21.7$ & $38 / 31.7$ & $24 / 20.0$ & $2.45 \pm 1.09$ \\
\hline I wish I could have more respect for myself & $30 / 25.0$ & $29 / 24.2$ & $36 / 30.0$ & $25 / 20.8$ & $2.47 \pm 1.08$ \\
\hline I certainly feel useless at times & $34 / 28.3$ & $37 / 30.8$ & $28 / 23.3$ & $21 / 17.5$ & $2.33 \pm 1.07$ \\
\hline At times I think I am no good at all & $21 / 17.5$ & $37 / 30.8$ & $28 / 23.3$ & $34 / 28.3$ & $2.63 \pm 1.08$ \\
\hline
\end{tabular}

Table 3. 6-Item Stigmatization Scale and Spearman's rho correlation coefficients between the age of the study participants

\begin{tabular}{|c|c|c|c|c|c|c|}
\hline 6-Item Stigmatization Scale & $\begin{array}{l}\text { Always } \\
n / \%\end{array}$ & $\begin{array}{l}\text { Very often } \\
n / \%\end{array}$ & $\begin{array}{c}\text { Sometimes } \\
n / \%\end{array}$ & $\begin{array}{l}\text { Not at all } \\
n / \%\end{array}$ & $\begin{array}{l}\text { Mean } \pm \text { SD } \\
\text { [points] }\end{array}$ & $\begin{array}{l}\text { Age } \\
\text { (rho) }\end{array}$ \\
\hline $\begin{array}{l}\text { Other people sometimes make annoying comments } \\
\text { about my skin disease }\end{array}$ & $11 / 9.2$ & $36 / 30.0$ & $54 / 45.0$ & 19/15.8 & $1.33 \pm 0.84$ & -0.15 \\
\hline Other people think that my skin disease is contagious & $19 / 15.8$ & $44 / 36.7$ & $41 / 34.2$ & $16 / 13.3$ & $1.58 \pm 0.90$ & -0.19 \\
\hline Others are not attracted to me due to my skin disease & $21 / 17.5$ & $48 / 40.0$ & $42 / 35.0$ & $9 / 7.5$ & $1.68 \pm 0.85$ & 0.11 \\
\hline I think that others stare at my skin disease & $30 / 25.0$ & $46 / 38.3$ & $34 / 28.3$ & $10 / 8.3$ & $1.80 \pm 0.91$ & 0.07 \\
\hline Other people avoid me due to my skin disease & 14/11.7 & $47 / 39.2$ & $35 / 29.2$ & $24 / 20.0$ & $1.43 \pm 0.94$ & -0.18 \\
\hline $\begin{array}{l}\text { Others feel uncomfortable touching me due to my skin } \\
\text { disease }\end{array}$ & $54 / 45.0$ & $28 / 23.3$ & $27 / 22.5$ & $11 / 9.2$ & $2.04 \pm 1.02$ & -0.26 \\
\hline
\end{tabular}


Table 4. Stigmatization level according to respondent sex

\begin{tabular}{|c|c|c|c|c|}
\hline 6-Item Stigmatization Scale & Sex & Mean & Mann-Whitney $U$-test & $P$-value \\
\hline \multirow{2}{*}{$\begin{array}{l}\text { Other people sometimes make annoying comments about my skin } \\
\text { disease }\end{array}$} & Women & 58.93 & \multirow[t]{2}{*}{0.49} & \multirow[t]{2}{*}{0.623} \\
\hline & Men & 61.88 & & \\
\hline \multirow[t]{2}{*}{ Other people think that my skin disease is contagious } & Women & 61.20 & \multirow[t]{2}{*}{0.22} & \multirow[t]{2}{*}{0.826} \\
\hline & Men & 59.89 & & \\
\hline \multirow[t]{2}{*}{ Others are not attracted to me due to my skin disease } & Women & 53.97 & \multirow[t]{2}{*}{2.03} & \multirow[t]{2}{*}{0.042} \\
\hline & Men & 66.21 & & \\
\hline \multirow[t]{2}{*}{ I think that others stare at my skin disease } & Women & 63.17 & \multirow[t]{2}{*}{0.82} & \multirow[t]{2}{*}{0.411} \\
\hline & Men & 58.16 & & \\
\hline \multirow[t]{2}{*}{ Other people avoid me due to my skin disease } & Women & 53.31 & \multirow[t]{2}{*}{2.21} & \multirow[t]{2}{*}{0.027} \\
\hline & Men & 66.79 & & \\
\hline \multirow[t]{2}{*}{ Others feel uncomfortable touching me due to my skin disease } & Women & 60.51 & \multirow[t]{2}{*}{0.003} & \multirow[t]{2}{*}{0.998} \\
\hline & Men & 60.49 & & \\
\hline
\end{tabular}

P-value-significance level.

Table 5. Spearman's rho correlation coefficients between self-esteem and stigmatization scores

\begin{tabular}{lc}
\hline Stigmatization & $\begin{array}{c}\text { Self-esteem } \\
\text { (rho) }\end{array}$ \\
\hline $\begin{array}{l}\text { Other people sometimes make annoying } \\
\text { comments about my skin disease }\end{array}$ & 0.10 \\
\hline $\begin{array}{l}\text { Other people think that my skin disease is } \\
\text { contagious }\end{array}$ & 0.01 \\
\hline $\begin{array}{l}\text { Others are not attracted to me due to my skin } \\
\text { disease }\end{array}$ & 0.23 \\
\hline \begin{tabular}{l} 
I think that others stare at my skin disease \\
\hline $\begin{array}{l}\text { Other people avoid me due to my skin disease } \\
\text { Others feel uncomfortable touching me due to } \\
\text { my skin disease }\end{array}$
\end{tabular} & 0.23 \\
\hline
\end{tabular}

Then, we verified if women and men differed in terms of their responses to questions about stigmatization. The analysis with Mann-Whitney U-test demonstrated that men less often than women felt unattractive to others and less often believed that people avoid them because of their skin condition (Table 4).

\section{Analysis of the relationship between self-esteem and stigmatization}

Analysis of Spearman's rho coefficients showed that the higher the self-esteem in the study participants the less often they considered themselves unattractive to others, less often believed that people gaze at their skin lesions or avoid them because of their condition (Table 5).

\section{Discussion}

In the case of psoriasis, patient's mentality can be both a cause of the disease and its consequence, con- tributing to a depressed mood, lower self-acceptance and self-worth, and underestimation of self-esteem [15-18].

Due to the presence of clinical signs visible to others and poor social awareness of the disease, psoriasis patients are not infrequently classified as different or stigmatized, and their value as human beings tends to decrease. The stigmatization may manifest as harsh statements, comments and hostile attitudes towards the diseased person. However, also psoriasis patients may stigmatize themselves discrediting their self-image and believing that the same opinion is also shared by the others [19, 20].

Krueger et al. emphasized that self-esteem may be a significant determinant of stigmatization [21]. Self-esteem reflects both one's perception by the others (physical attractiveness, interpersonal skills) and the way he/ she perceives himself/herself (self-image) [21].

Our study with the RSES scale demonstrated that women had slightly lower self-esteem scores than men (24.59 points vs. 26.48 points). Up to $64.3 \%$ of women and $57.8 \%$ of men presented with very low, low or moderate self-esteem. However, respondents' sex did not exert a significant effect on the distribution of self-esteem scores $(p=0.345)$.

Aydin et al. demonstrated that psoriasis patients had lower self-esteem than healthy persons, but did not find a link between duration of the disease and self-esteem scores. According to those authors, management of psoriasis patients should also be adjusted for their self-esteem or quality of life as only such attitude may increase the likelihood of better treatment outcome [22].

A significant relationship between sex and selfesteem was previously reported by Kouris et al. [23]. According to those authors, lower self-esteem in women might result from the fact that they pay more attention 
to their image than men. In this context, the results of our study should not be considered surprising.

Other authors showed that psoriasis exerted a significant effect on patient self-image, which might contribute to lower self-esteem, and hence affect the quality of life, cause sexual problems and anxiety. Up to $89 \%$ of the patients participating in previous studies felt shame and embarrassment, 58\% experienced anxiety, $42 \%$ lacked self-confidence, and $24 \%$ had a history of a depressive episode [24-26].

According to Nazik et al. [27], self-esteem correlated with the severity of psoriasis (PASI). In this study, we surveyed patients who were homogenous in terms of their PASI scores $(\leq 10)$, and thus, we cannot compare our findings with the results published by other authors.

Stigmatization is a multistage process during which a person is assigned an unacceptable trait, and as a result, is considered strange, different or imperfect. The assigned unacceptable trait predominates observer's way of thinking, outnumbering other traits and making the stigmatized person perceived primarily from the perspective of his/her "defect". The stigma of the disease contributes to social exclusion and isolation, and hence, diminishes one's opportunities, chances for selffulfilment, and eventually results in the loss of social status. Stigmatization may also negatively affect one's self-esteem, the sense of self-efficacy, psychological wellbeing and quality of life. However, some authors consider self-stigmatization as an opportunity to gain or regain self-control over one's life and treatment, which is associated with the improvement of self-esteem and the sense of self-satisfaction [28].

The results of our study conducted with the 6-Item Stigmatization Scale confirmed that psoriasis patients experienced negative reactions from others, which unequivocally implies that they were socially stigmatized. Moreover, psoriasis turned out to be the skin disease which had been most often analysed in the context of its effect on the stigmatization level [29].

The study conducted by Hrehorów et al. [30], with the same 6-Item Stigmatization Scale, demonstrated that only $9.8 \%$ of the respondents did not have the sense of stigmatization. According to Dimitrov et al., only $12 \%$ of participants of their study did not feel stigmatized at all, and another $16.7 \%$ presented with a minimum stigmatization level [31]. When asked about their most serious concerns, patients participating in the two studies mentioned above pointed to comments from the others and a common social belief that psoriasis is a contagious disease [30, 31]. Also, in our study, psoriasis patients identified those problems as important, but their most serious concern was verbalized in the statement "people who touch me feel discomfort because of my skin lesions", chosen by $45 \%$ of the respondents.

In turn, Dimitrov et al. identified location of the lesions (face) and itchiness as the strongest determinants of stigmatization [31].
Planning this study, we hypothesized that age and sex might determine a tendency to lower self-esteem and stigmatization. Indeed, the study confirmed that the older the respondents, the less often (in their subjective opinion) they heard harsh comments about their ailments, the less frequently they had an impression that their disease is considered a contagious condition or that others feel discomfort touching their skin lesions, and the less often they were avoided because of their illness. Our findings are consistent with the results published by Lu et al. [12] who found a higher degree of stigmatization in younger persons, with either psoriasis or atopic dermatitis. Similar observations regarding a link between age and stigmatization have also been reported by other authors [32, 33].

Our observations regarding a relationship between stigmatization and sex are consistent with the results reported by Schmid-Ott et al. [34, 35] and Ginsburg and Link [13], who demonstrated that women had a stronger sense of stigmatization than men. The differences in the degree of stigmatization in women and men with psoriasis may result from their different perception of their body image and different satisfaction with the latter. This hypothesis is also supported by the results published by Smith et al., according to whom women pay more attention to their image than men, and are generally less satisfied in this matter [36]. Lower self-image scores in women in whom the severity of skin lesions is the same as in men may be a cause of the stronger sense of stigmatization and greater impairment of social functioning, which is eventually reflected by the worse quality of life [36].

Despite a growing number of published papers about stigmatization in dermatological patients [29], still little is known about the link between self-esteem and the sense of being stigmatized. Stigmatized persons perceive themselves in the context of their illness which makes them distinct from others. Therefore, their self-image may be distorted, underestimated and negatively affect their self-esteem. Identification with such distorted self-image causes social withdrawal, self-isolation, or promotes a demanding attitude towards healthy persons. As a result of such attitude, individuals with low self-esteem are less socially accepted, and in effect, may feel stigmatized [10].

\section{Conclusions}

Our findings demonstrate clearly that both self-esteem and stigmatization are significant components of psoriasis' influence on the patient life. Psoriasis should not be considered merely as a somatic problem, but also as a significant psychological and social burden. Thus, aside from the choice of an effective anti-psoriatic treatment, also the psychological well-being of the patients should be a priority. Only a holistic approach may improve the quality of life in psoriasis patients, boost their 
acceptance of the illness and its consequences, and make them feel fully valuable persons, free from limitations imposed by their external appearance.

\section{Conflict of interest}

The authors declare no conflict of interest.

\section{References}

1. Gliński W, Wolska H. Consensus PTD. Zasady postępowania w łuszczycy. Dermatol Rev 2000; 87: 465-71.

2. Kimyai-Asadi A, Usman A. The role of psychological stress in skin disease. J Cutan Med Surg 2001; 5: 140-5.

3. Saez-Rodriguez M, Noda-Cabrera A, Alvalez-Tejera S, et al. The role of psychological factors in palmoplantar pustulosis. J Eur Acad Dermatol Venereol 2002; 16: 325-7.

4. Rodriguez-Cerdeira C, Pera-Grasa JT, Molares A, et al. Psychodermatology: past, present and future. Open Dermatol J 2011; 5: 21-7.

5. Baumeister RF, Campbell JD, Krueger JI, et al. Does high selfesteem cause better performance, interpersonal success, happiness, or healthier lifestyles? Psychological Science in the Public Interest 2003; 4: 1-44.

6. Laguna M, Lachowicz-Tabaczek K, Dzwonkowska I. Skala samooceny SES Morrisa Rosenberga - polska adaptacja metody. Psychologia Społeczna 2007; 02: 164-76.

7. Rosenberg M. Society and the Adolescent Self-image. Princeton University Press, Princeton 1965.

8. Link BP, Phelan JC. Conceptualizing stigma. Annual Review of Socjology 2001; 27: 363-85.

9. Jackowska E. Stygmatyzacja i wykluczenie społeczne osób chorujących na schizofrenię - przegląd badań i mechanizmy psychologiczne. Psychiatr Pol 2009; XLIII: 655-70.

10. Czykwin E. Stygmat społeczny. Wydawnictwo Naukowe PWN, Warszawa 2007,

11. Hrehorów E, Szepietowski J, Reich A, et al. Instruments for stigmatization evaluation in patients suffering from psoriasis: Polish language versions. Dermatol Klin 2006; 8: 253-8.

12. Lu Y, Duller P, van der Valk PGM, et al. Helplessness as predictor of perceived stigmatization in patients with psoriasis and atopic dermatitis. Dermatol Psychosom 2003; 4: 146-50.

13. Ginsburg IH, Link BG. Feelings of stigmatization in patients with psoriasis. J Am Acad Dermatol 1989; 20: 53-63.

14. Dimitrov D, Szepietowski J. Instruments to assess stigmatization in dermatology. Postepy Hig Med Dosw (Online) 2017; 71: 901-5.

15. Richards HL, Fortune DG, Chong SLP, et al. Divergent beliefs about psoriasis are associated with increased psychological distress. J Invest Dermatol 2004; 123: 49-56.

16. Łuczkowska M, Żaba R. Łuszczyca. In: Psychologiczne i medyczne aspekty chorób skóry. Rzepa T, Szepietowski J, Żaba R (eds). Medical Publishing House Cornetis, Wrocław 2011; 166-70.

17. Zachariae R, Zachariae J, Blomqvist K, et al. Self-reported stress reactivity and psoriasis-related stress of Nordic psoriasis sufferers. J Eur Acad Dermatol 2004; 18: 27-36.

18. Baranowska A, Krajewska-Kułak E, Jankowiak B, et al. Psychodermatologia współczesnym wyzwaniem dla zespołu terapeutycznego. Probl Piel 2012; 20: 512-8.

19. Wahl A, Gjengedal E, Hanestad BR. The bodily suffering of living with severe psoriasis: in depth interview with 22 hos- pitalised patients with psoriasis. Qual Health Res 2002; 12: 250-61.

20. Kent G, Keohane S. Social anxiety and disfigurement: the moderating effects of fear of negative evaluation and past experience. Br J Clin Psychol 2001; 40: 23-34.

21. Krueger G, Koo J, Lebwohl M, et al. The impact of psoriasis on quality of life: results of a 1998 National Psoriasis Foundation patient-membership survey. Arch Dermatol 2001; 137: 280-4.

22. Aydin E, Atis G, Bolu A, et al. Identification of anger and self-esteem in psoriasis patients in a consultation-liaison psychiatry setting: a case control study. Psychiatry Clin Psychopharmacol 2017; 27: 222-6.

23. Kouris A, Christodoulou C, Stefanaki C, et al. Quality of life and psychosocial aspects in Greek patients with psoriasis: a cross-sectional study. An Bras Dermatol 2015; 90: 841-5.

24. Russo PA, Ilchef R, Cooper AJ. Psychiatric morbidity in psoriasis: a review. Australas J Dermatol 2004; 45: 155-9.

25. Khoury LR, Danielsen PL, Skiveren J. Body image altered by psoriasis. A study based on individual interviews and a model for body image. J Dermatolog Treat 2014; 25: 2-7.

26. Jankowiak B, Kowalewska B, Khvorik D, et al. The level of stigmatization and depression of patients with psoriasis. Iran J Public Health 2016; 45: 690-2.

27. Nazik H, Nazik S, Ful F. Body image, self-esteem, and quality of life in patients with psoriasis. Indian Dermatol Online J 2017; 8: 343-6.

28. Świtaj P. Piętno choroby psychicznej. Post Psychiatr Neurol 2005; 14: 137-44.

29. Dimitrov D, Szepietowski J. Stigmatization in dermatology with a special focus on psoriatic patients. Postepy Hig Med Dosw 2017; 71: 1115-22.

30. Hrehorów E, Salomon J, Matusiak $Ł$, et al. Patients with psoriasis feel stigmatized. Acta Derm Venereol 2012; 92: 67-72.

31. Dimitrov D, Matusiak $Ł$, Szepietowski J. Stigmatization in Arabic psoriatic patients in United Arab Emirates - a cross sectional study. Adv Dermatol Alergol 2019; 36: 425-30.

32. Stankler $L$. The effect of psoriasis on the sufferer. Clin Exp Dermatol 1981; 6: 303-6.

33. Van der Schaar WW. Psychometric investigation 48 Dutch patients suffering from psoriasis. Psychother Psychosom 1977; 27: 159-62.

34. Schmid-Ott G, Kunsebeck HW, Jager B, et al. Significance of the stigmatization experience of psoriasis patients: a 1 -year follow-up of the illness and its psychosocial consequences in men and women. Acta Dermatovenereol 2005; 85: 27-32.

35. Schmid-Ott G, Schallmayer S, Calliess IT. Quality of life in patients with psoriasis and psoriasis arthritis with a special focus on stigmatization experience. Clin Dermatol 2007; 25: 547-54.

36. Smith D, Thompson JK, Raczyński JM, Hilner J. Body image among men and women in a biracial cohort: the CARDIA study. Int J Eat Disorder 1999; 25: 71-82. 